\section{Ebola Virus Disease: What Canadian Hospital Pharmacists Need To Know}

The ongoing epidemic of Ebola virus disease (EVD) in West Africa has been the most catastrophic in history, with widespread transmission in Guinea, Liberia, and Sierra Leone. ${ }^{1}$ As of March 2015, there had been over 25000 probable, suspected, or confirmed cases and more than 10000 deaths. ${ }^{1}$ Cases have also appeared in other countries, including the United States. ${ }^{1}$ In response to the epidemic, the Public Health Agency of Canada has worked to improve current response measures, which has included forming Ebola Rapid Response Teams, to be deployed to support provincial and territorial health authorities if necessary. ${ }^{2}$ Provinces have also designated specially equipped hospitals for treatment of patients with EVD. As members of the health care team, hospital pharmacists require a working knowledge of EVD and its management, given that travel and health care-related EVD transmission is possible in Canada (Table 1).

\section{Canadian Hospital Pharmacy Preparedness}

Canadian hospital pharmacies must establish EVD procedures for the procurement and distribution of medications to maintain staff and patient safety. ${ }^{3-5}$ Pharmacies should ensure that institutional policies and procedures concerning patient isolation include procedures to minimize patient contact when medications are ordered..$^{3-5}$
For example, the use of paper orders should be avoided in the rooms of patients with EVD. 5

Procedures for dispensing, delivering, documenting, and disposing of medications for EVD patients in isolation are essential. ${ }^{3,5}$ Health care providers must be able to manipulate packaging and administer medications while wearing personal protective equipment (PPE). ${ }^{3}$ Disposable medication containers that can be incinerated, without staples or sharp objects, are preferred. ${ }^{3}$ Other operational considerations, such as unit-dose packaging, with delivery by automated cabinets or a pneumatic tube system in a non-isolation or clean area, and establishment of a satellite pharmacy near the isolation unit, may also be helpful. ${ }^{3,5}$ Usual procedures for documentation of medication administration may have to be adapted for EVD patients in isolation. ${ }^{5}$ Policies for documentation and disposal of controlled substance waste originating from potential or confirmed EVD patients must be established. Also, procedures for replacement of code carts and their contents in EVD isolation rooms are essential. ${ }^{5}$ Furthermore, a process is needed for crediting medications delivered for but not administered to EVD patients. ${ }^{5}$

The hospital pharmacy may be responsible for procuring investigational medications, a situation that would require coordination between the manufacturer, Health Canada, and the institutional research ethics board, in accordance with local policies for investiga-

Table 1. Informational Resources

\begin{tabular}{|c|c|c|}
\hline Resource & Comments & Web Address* \\
\hline $\begin{array}{l}\text { American Society of Health-System } \\
\text { Pharmacists: Ebola Resource Center }\end{array}$ & $\begin{array}{l}\text { Ebola and pandemic preparedness } \\
\text { checklist for pharmacy }\end{array}$ & $\begin{array}{l}\text { www.ashp.org/menu/PracticePolicy/ } \\
\text { ResourceCenters/Ebola }\end{array}$ \\
\hline $\begin{array}{l}\text { Canadian guidelines } \\
\text { (CCCS, CAEP, and AMMI) }\end{array}$ & $\begin{array}{l}\text { Clinical management of patients } \\
\text { with Ebola virus disease }\end{array}$ & www.ammi.ca/guidelines/ \\
\hline $\begin{array}{l}\text { Centers for Disease Control } \\
\text { and Prevention (US) }\end{array}$ & Information on Ebola virus disease & www.cdc.gov/vhf/ebola/index.html \\
\hline Government of Canada & $\begin{array}{l}\text { Designated Ebola virus disease } \\
\text { hospitals in Canada }\end{array}$ & $\begin{array}{l}\text { www.healthycanadians.gc.ca/ } \\
\text { diseases-conditions-maladies- } \\
\text { affections/disease-maladie/ebola/ } \\
\text { treatment-traitement/hospitals- } \\
\text { hopitaux/index-eng.php }\end{array}$ \\
\hline Public Health Agency of Canada & Information on Ebola virus disease & $\begin{array}{l}\text { www.phac-aspc.gc.ca/lab-bio/res/ } \\
\text { psds-ftss/ebola-eng.php }\end{array}$ \\
\hline \multirow[t]{2}{*}{ World Health Organization } & Overview of Ebola epidemic & $\begin{array}{l}\text { http://who.int/csr/disease/ebola/ } \\
\text { one-year-report/introduction/en/ }\end{array}$ \\
\hline & $\begin{array}{l}\text { Updates on Ebola research and } \\
\text { development: vaccines, therapies, } \\
\text { and diagnostics }\end{array}$ & $\begin{array}{l}\text { www.who.int/medicines/ebola- } \\
\text { treatment/2015-0130_Ebola_RD_ } \\
\text { Update.pdf?ua=1 }\end{array}$ \\
\hline
\end{tabular}

$\overline{\mathrm{AAMMI}}=$ Association of Medical Microbiology and Infectious Disease Canada,

CAEP = Canadian Association of Emergency Physicians, CCCS = Canadian Critical Care Society.

*Cited March 28, 2015. 
tional drug use, as well as federal and international regulations. ${ }^{3-5}$ If EVD is suspected, the provincial public health authority should be notified promptly. Discussions regarding procurement of investigational medications should include the latest results of clinical trials and drug availability. Pharmacists may want to increase their understanding of available manufacturer(s), mechanism(s), and therapeutic use(s) of these agents in both individual cases and larger trials, as part of the institution's preparation for EVD (Table 2).

Pharmacy staff members have an obligation to familiarize themselves with institutional EVD policies and procedures. Departments should estimate the increased number of dispensary and clinical pharmacy staff needed per EVD case. Clinical pharmacists who will participate in direct care of patients with EVD must be identified in advance, must receive PPE training, and must have a clear understanding of their role in patient care. ${ }^{3}$

\section{Role of Canadian Hospital Pharmacists}

Hospitals with EVD patients may need additional dedicated pharmacy staff to facilitate procurement, preparation, and distribution of therapy. Although all Canadian hospital pharmacists need to have an understanding of EVD, those working in critical care, infectious diseases, and the emergency department will likely play the largest roles in clinical management of this disease. ${ }^{3}$ Investigational drug services pharmacists may also be involved in procuring and managing investigational EVD therapies, including inventory control and ensuring all regulatory requirements are met. ${ }^{3}$

\section{Treatment}

As of early spring 2015, no medications had been approved for the prevention or treatment of EVD. ${ }^{6,7}$ Supportive care may allow time for the development of adequate antibody response. Adminis-

\section{Table 2. Investigational Medications for Ebola Virus Disease (EVD) ${ }^{6-8}$}

\begin{tabular}{|c|c|c|c|c|}
\hline Medication & Manufacturer & $\begin{array}{l}\text { Mechanism } \\
\text { of Action }\end{array}$ & $\begin{array}{l}\text { Dosing and } \\
\text { Use to Date }\end{array}$ & Comments \\
\hline \multicolumn{5}{|c|}{ Not readily available in Canada } \\
\hline Brincidofovir & Chimerix & Unknown for EVD & $\begin{array}{l}200 \mathrm{mg} \mathrm{PO} \times 1 \text {, } \\
\text { then } 100 \mathrm{mg} \text { twice } \\
\text { weekly } \times 2 \text { weeks } \\
\text { (total } 5 \text { doses) } \\
\text { Used in } 5 \text { patients } \\
\text { (United States) }\end{array}$ & $\begin{array}{l}\text { Brincidofovir is a lipid conjugate of cidofovir. No } \\
\text { safety or efficacy data exist for the use of this drug } \\
\text { in treating EVD in humans or animals. Chimerix } \\
\text { recently stopped participation in a clinical trial } \\
\text { involving Médecins Sans Frontières in Liberia } \\
\text { because of a significant decrease in the number of } \\
\text { EVD cases diagnosed in } 2015 .{ }^{9}\end{array}$ \\
\hline Favipiravir & $\begin{array}{l}\text { Fuji Film/ } \\
\text { Toyama Chemical }\end{array}$ & $\begin{array}{l}\text { Nucleotide analogue } \\
\text { that inhibits RNA } \\
\text { polymerase and } \\
\text { causes lethal } \\
\text { mutagenesis following } \\
\text { incorporation into } \\
\text { viral RNA }\end{array}$ & $\begin{array}{l}150 \mathrm{mg} / \mathrm{kg} \text { PO bid } \\
\times 14 \text { days } \\
\text { (influenza dosing) } \\
\text { Used to treat } 1 \\
\text { patient with EVD } \\
\text { (France) }\end{array}$ & $\begin{array}{l}\text { Favipiravir, which is currently in the late stages of } \\
\text { testing against influenza, has also been tested in } \\
\text { cell cultures and small-animal EBV models. The } \\
\text { doses required to treat Ebola are likely to be } 2-5 \\
\text { times higher than those for influenza. The drug } \\
\text { may have teratogenic and embryotoxic effects. } \\
\text { Large amounts are available, as the drug is in phase } \\
3 \text { influenza studies. }\end{array}$ \\
\hline TKM-Ebola & Tekmira & $\begin{array}{l}\text { Small interfering RNA } \\
\text { that hinders } 3 \text { out of } \\
7 \text { Ebola proteins } \\
\text { (L, VP24, and VP35 } \\
\text { proteins) }\end{array}$ & $\begin{array}{l}2.4 \mathrm{mg} / \mathrm{kg} \\
\text { per IV dose }\end{array}$ & $\begin{array}{l}\text { TKM-Ebola showed promise after initial studies in } \\
\text { nonhuman primates. The phase } 1 \text { trial was put on } \\
\text { hold because of adverse effects (increased cytokine } \\
\text { levels, headache, dizziness, and tachycardia). }\end{array}$ \\
\hline ZMapp & $\begin{array}{l}\text { Mapp } \\
\text { Biopharmaceutical } \\
\text { Inc. }\end{array}$ & $\begin{array}{l}\text { Combination of } 3 \\
\text { humanized } \\
\text { monoclonal antibodies } \\
\text { that bind and coat } \\
\text { the viral envelope. }\end{array}$ & $\begin{array}{l}\text { Dosing unknown } \\
\text { Used in } 7 \text { patients, } \\
\text { of whom } 5 \text { survived }\end{array}$ & $\begin{array}{l}\text { Derived from the Nicotiana benthamiana tobacco } \\
\text { plant, ZMapp has shown survival benefits in } \\
\text { nonhuman primates infected with EBV. It has been } \\
\text { used emergently to treat } 7 \text { human patients. The } \\
\text { production process is complex, and the supply of } \\
\text { the drug is currently exhausted. }\end{array}$ \\
\hline \multicolumn{5}{|c|}{ Readily available in Canada } \\
\hline $\begin{array}{l}\text { Amiodarone, } \\
\text { chloroquine, } \\
\text { clomiphene, } \\
\text { dronedarone, } \\
\text { verapamil }\end{array}$ & $\begin{array}{l}\text { Brand-name and } \\
\text { generic } \\
\text { manufacturers } \\
\text { available (except } \\
\text { for dronedarone } \\
\text { [brand name only]) }\end{array}$ & $\begin{array}{l}\text { Inhibits entry of virus } \\
\text { into host cells }\end{array}$ & $\begin{array}{l}\text { Dosing unknown } \\
\text { In vitro studies only }\end{array}$ & $\begin{array}{l}\text { The Emergency Amiodarone Study against Ebola } \\
\text { (EASE) trial is a randomized, open-label study } \\
\text { underway in Sierra Leone to compare the } \\
\text { combination of amiodarone and best supportive } \\
\text { care with best supportive care alone. }{ }^{10}\end{array}$ \\
\hline Lamivudine & $\begin{array}{l}\text { Brand-name and } \\
\text { generic } \\
\text { manufacturers } \\
\text { available }\end{array}$ & $\begin{array}{l}\text { Cytosine analogue } \\
\text { that inhibits RNA } \\
\text { polymerase }\end{array}$ & $\begin{array}{l}\text { Dosing unknown } \\
\text { Used by one Liberian } \\
\text { doctor in } 15 \text { patients, } \\
\text { of whom } 13 \text { are } \\
\text { reported to have } \\
\text { survived }\end{array}$ & $\begin{array}{l}\text { The Scientific and Technical Advisory Committee on } \\
\text { Ebola Experimental Interventions of the World } \\
\text { Health Organization stated that available data did } \\
\text { not show lamivudine to have antiviral activity } \\
\text { against Ebola. The committee does not currently } \\
\text { recommend its use for Ebola treatment. However, } \\
\text { the drug is listed as a potential option for further } \\
\text { investigation. }{ }^{11}\end{array}$ \\
\hline
\end{tabular}


tration of IV fluids, replacement of electrolytes, treatment of concurrent infections and secondary bacterial infections, nutritional support, administration of antinauseants and analgesics, and management of bleeding are essential aspects of care for those with EVD. ${ }^{6}$ As clinical trials are conducted, investigational treatments for EVD may play a larger role. Investigational medications include brincidofovir, favipiravir, TKM-Ebola, ZMapp, amiodarone, chloroquine, clomiphene, dronedarone, lamivudine, and verapamil (Table 2). ${ }^{6,7}$ Therapies based on blood products obtained from convalescing EVD patients and vaccines, including the VSV-EBOV vaccine developed by the National Microbiology Laboratory of the Public Health Agency of Canada, are also being assessed for their potential use in treating and preventing EVD. ${ }^{6}$

\section{Conclusion}

Given the important role of hospital pharmacists on the front lines of patient care, an understanding of EVD management and the development of EVD-specific hospital pharmacy policies and procedures are essential.

\section{References}

1. 2014 Ebola outbreak in West Africa-case counts. Atlanta (GA): Centers for Disease Control and Prevention; 2015 [cited 2015 Mar 31]. Available from: www.cdc.gov/vhf/ebola/outbreaks/2014-west-africa/case-counts.html

2. Canada's response to Ebola. Ottawa (ON): Government of Canada; 2015 [cited 2015 Feb 2]. Available from: www.healthycanadians.gc.ca/ diseases-conditions-maladies-affections/disease-maladie/ebola/responsereponse/index-eng.php

3. Guarascio AJ, Faust AC, Sheperd L, O’Donnell LA. Ebola virus disease: roles and considerations for pharmacists. Ann Pharmacother. 2015;49(2): 247-9.

4. Traynor K. Pharmacists' investigational drug services aid Ebola response. Am J Health Syst Pharm. 2014;71(23):2000, 2004, 2006.

5. Pharmacy checklist: Ebola and pandemic preparedness. Bethesda (MD): American Society of Health-Systems Pharmacists; 2015 [cited 2015 Feb 2]. Available from: www.ashp.org/menu/PracticePolicy/ResourceCenters/Ebola

6. Bishop BM. Potential and emerging treatment options for Ebola virus disease. Ann Pharmacother. 2015;49(2):196-206.

7. Potential Ebola therapies and vaccines. Geneva (Switzerland): World Health Organization; 2014 [cited 2015 Feb 2]. Available from: http://apps.who.int/ iris/bitstream/10665/137590/1/WHO_EVD_HIS_EMP_14.1_eng.pdf
8. Gehring G, Rohrmann K, Atenchong N, Mittler E, Becker S, Dahlmann $\mathrm{F}$, et al. The clinically approved drugs amiodarone, dronedarone, and verapamil inhibit filovirus cell entry. J Antimicrob Chemother. 2014; 69(8):2123-31.

9. Chimerix focusing efforts on CMV and adenovirus pivotal trials: brincidofovir will not be considered in further clinical trials in Ebola virus disease. Durham (NC): Chimerix Inc; 2015 [cited 2015 Feb 10]. Available from: http://ir.chimerix.com/releasedetail.cfm?ReleaseID=893927

10. Clinical study to assess efficacy and safety of amiodarone in treating patients with Ebola virus disease (EVD) in Sierra Leone. EASE (EMERGENCY Amiodarone Study Against Ebola) [study registration]. Bethesda (MD): ClinicalTrials.gov; 2014 [record updated 2014 Dec 3; cited 2015 Feb 10]. Available from: https://www.clinicaltrials.gov/ct2/show/NCT02307591? term $=$ NCT02307591\&rank $=1$

11. WHO meeting of the Scientific and Technical Advisory Committee on Ebola experimental interventions_-briefing note. Geneva (Switzerland): World Health Organization; 2014 [cited 2015 Feb 10]. Available from: www.who.int/medicines/ebola-treatment/scientific_tech_meeting/en/

Tasha D Ramsey, RPh, BSc(Pharm), ACPR, PharmD

Clinical Pharmacy Specialist - Infectious Diseases

Pharmacy Services, Kelowna General Hospital

Kelowna, British Columbia

Jennifer M Tung, BSC(Pharm), ACPR, PharmD

Clinical Pharmacist

Sunnybrook Health Sciences Centre

Toronto, Ontario

Heather Balogh, BSP

Staff Pharmacist

Regina Qu'Appelle Health Region

Regina, Saskatchewan

April J Chan, BSc(Pharm), ACPR, PharmD

Pharmacist, Antimicrobial Stewardship Program

St Joseph's Health Centre

Toronto, Ontario

Tasha Ramsey is also a Clinical Instructor with the Faculty of Pharmaceutical Sciences, University of British Columbia, Vancouver, British Columbia.

Competing interests: None declared. 